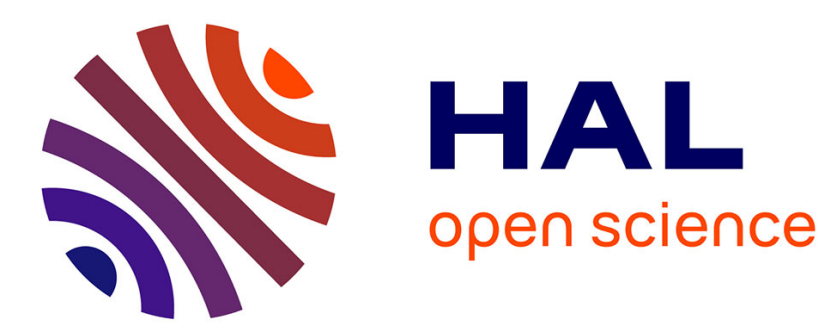

\title{
THE DETERIORATION OF BETA ALUMINA DURING ELECTROLYSIS
}

\author{
D. Demott, B. Redfern
}

\section{To cite this version:}

D. Demott, B. Redfern. THE DETERIORATION OF BETA ALUMINA DURING ELECTROLYSIS. Journal de Physique Colloques, 1976, 37 (C7), pp.C7-423-C7-427. 10.1051/jphyscol:1976796 . jpa00216956

\section{HAL Id: jpa-00216956 https://hal.science/jpa-00216956}

Submitted on 1 Jan 1976

HAL is a multi-disciplinary open access archive for the deposit and dissemination of scientific research documents, whether they are published or not. The documents may come from teaching and research institutions in France or abroad, or from public or private research centers.
L'archive ouverte pluridisciplinaire HAL, est destinée au dépôt et à la diffusion de documents scientifiques de niveau recherche, publiés ou non, émanant des établissements d'enseignement et de recherche français ou étrangers, des laboratoires publics ou privés. 


\title{
THE DETERIORATION OF BETA ALUMINA DURING ELECTROLYSIS
}

\author{
D. S. DEMOTT and B. A. W. REDFERN
}

British Railways Research and Development Division, Derby, U. K.

\begin{abstract}
Résumé. - La raison principale de la défaillance de l'électrolyte céramique d’alumine béta dans des éléments sodium-soufre est le départ de la conduction électronique à travers l'électrolyte, avec la réduction du rendement faradique qui en résulte, suivie, dans certains cas, de la défaillance complète de l'élément. A cette phase finale le sodium métallique aura pénétré dans la céramique.

Il a été suggéré que cette pénétration résulte de la propagation des fissures, mais on a remarqué que l'électrolyte se fonce fortement avant cette phase finale. Pour établir le rôle de ce brunissement dans le processus de défaillance, on a examiné par thermoluminescence la présence de centres colorés.
\end{abstract}

\begin{abstract}
The major cause of the failure of beta alumina ceramic electrolyte in sodium/ sulphur cells is the onset of electronic conduction through the electrolyte with a consequential reduction in Faradaic efficiency followed, in some cases, by complete failure of the cell. At this final stage sodium metal has penetrated the ceramic.

Although crack propagation has been suggested as the cause of this penetration, it has been observed that the electrolyte darkens significantly before this final stage. In order to establish the role of this darkening in the failure sequence, the existence of colour centres has been examined by thermoluminescence.
\end{abstract}

1. Introduction. - Beta alumina is used as the solid electrolyte in sodium/sulphur cells because of its exceptionally high $\mathrm{Na}^{+}$ion conductivity and negligibly low electronic conductivity [1-5]. It has the approximate formula $\mathrm{Na}_{2} \mathrm{O} .11 \mathrm{Al}_{2} \mathrm{O}_{3}$ and the structure (hexagonal, $\mathrm{P} 6_{3} / \mathrm{mmc}$ ) consists of layers of loosely bonded sodium ions between spinel-type blocks of aluminium and oxygen ions [6-8] as shown in figure 1 . The mobility of the sodium ions within these planes is extremely high. Several structural variations are known to occur ; the most important of these is termed beta" alumina (rhombohedral, $\mathrm{R} \overline{\mathrm{3}} \mathrm{m}$ ) which is also shown in figure 1. This is preferred for use as an electrolyte because of its superior conductivity ( $\sim 0.2 \mathrm{ohm}^{-1} \cdot \mathrm{cm}^{-1}$ at $350^{\circ} \mathrm{C}$ compared to $\sim 0.05 \mathrm{ohm}^{-1} . \mathrm{cm}^{-1}$ for the beta form). It has three spinel blocks per unit cell related by a threefold screw axis, compared to the two related by a twofold screw axis in beta alumina $[8,9]$, and has a formula approximating to $\mathrm{Na}_{2} \mathrm{O} .5 \mathrm{Al}_{2} \mathrm{O}_{3}$. This is a highly defective structure, the excess sodium relative to the beta alumina formula being compensated by aluminium ion vacancies. Some of these defects can be removed, and the material stabilised, by doping with $\mathrm{Mg}^{2+}$ or $\mathrm{Li}^{+}$. These ions occupy $\mathrm{Al}$ sites within the spinel blocks, $\mathrm{Mg}^{2+}$ probably preferring the four co-ordinate sites and $\mathrm{Li}^{+}$ the six co-ordinate sites, although the detailed nature of the remaining defects is not fully established.

Failure of the polycrystalline beta alumina electrolyte in sodium/sulphur cells has frequently been due to

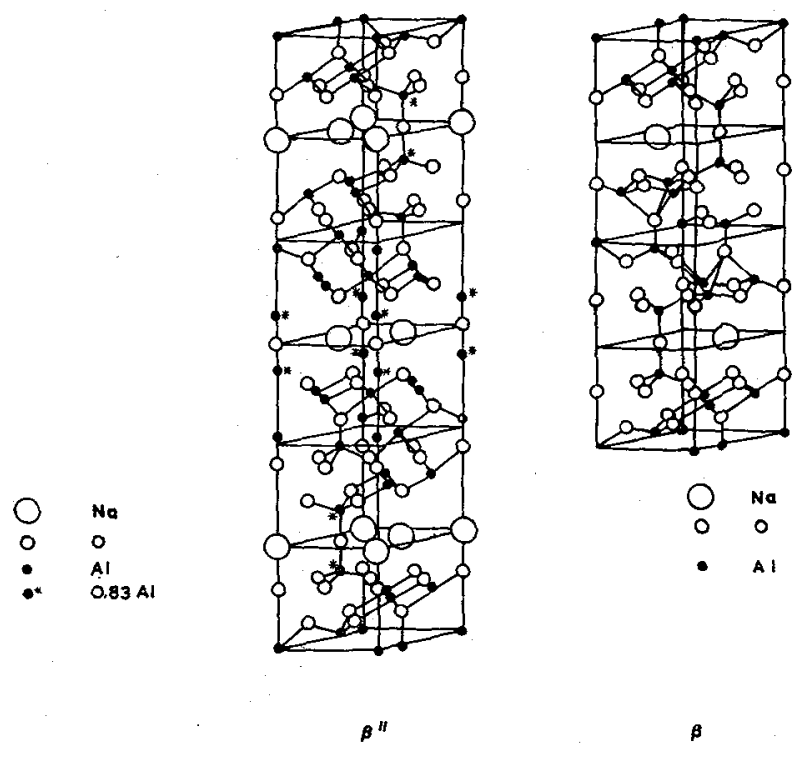

FIG. 1. - The crystal structures of beta and beta" alumina.

penetration of the ceramic by metallic sodium, which gives rise to an electronic component of conduction. It has been suggested by Armstrong, Dickinson and Turner [10] and by Richman and Tennenhouse [11] that the penetration can arise by crack propagation within the ceramic. There seems little doubt that this does occur in some materials. However, in our tests 
there is considerable evidence that localised filamentary darkening of the electrolyte after passage of current (often loosely described as dendrites) is not always associated with cracking. Also the extent of penetration depends upon the specific dopants used in the beta alumina. For instance, polycrystalline ceramic stabilised as beta" phase by $\mathrm{MgO}$ and $\mathrm{Li}_{2} \mathrm{O}$ combined is much more prone to penetration and increased electronic conduction than material stabilised with $\mathrm{Li}_{2} \mathrm{O}$ alone, although the microstructures are almost identical. Examination of the latter material prior to detectable electronic conduction revealed general darkening spreading inward from the sodium metal interface.

A similar darkening has been observed as a result of mass transfer of anion vacancies in yttria stabilised zirconia [12] ; Thorp, Aypar and Ross [13] also found E. S. R. evidence for the presence of F-centres consequent to blackening of this material. It is also possible that our dendrites are a localised form of the same phenomenon.

To investigate the occurrence and characteristics of colour centres in beta alumina and to examine material that has become darkened as a result of $\mathrm{Na}^{+}$transport, we have performed some simple thermoluminescence experiments.

2. Experimental. - Beta" alumina tubes $15 \mathrm{~cm}$ long, $1.5 \mathrm{~cm}$ diameter, wall thickness $0.2 \mathrm{~cm}$, were prepared by conventional ceramic techniques. Two compositions were subsequently tested, namely :

Composition (A) $8.9 \% \mathrm{Na}_{2} \mathrm{O}, 0.7 \% \mathrm{Li}_{2} \mathrm{O}$, balance $\mathrm{Al}_{2} \mathrm{O}_{3}$.

Composition (B) $8.9 \% \mathrm{Na}_{2} \mathrm{O}, \quad 0.5 \% \mathrm{Li}_{2} \mathrm{O}$, $2.0 \% \mathrm{MgO}$, balance $\mathrm{Al}_{2} \mathrm{O}_{3}$.

Both were polycrystalline with an average grain size of about 10 microns and with a beta" phase content of $>90 \%$, the remainder being the beta phase.

The tubes were subjected to a $\mathrm{Na}^{+}$current density of $500 \mathrm{~mA} \cdot \mathrm{cm}^{-2}$ at $350^{\circ} \mathrm{C}$ in $\mathrm{Na} /$ beta" alumina/ $^{\prime} \mathrm{Na}$ test cells as shown in figure 2 . A relay was used to cycle the sodium level between the upper and lower wire probes, by reversal of the direction of current flow through the tube. The time required for the sodium level to traverse the volume between these probes is directly related by Faraday's law to the number of coulombs passed through the tube. If any electronic component of conduction is present, however, this time will be longer. Hence, the onset of electronic conduction is detected by a lengthening of the cycle times.

Rings cut from these beta" alumina tubes were used for subsequent irradiation and thermoluminescence experiments. Sections cut from the tops of the tubes before the $\mathrm{Na} / \mathrm{beta}^{\prime \prime}$ alumina/ $\mathrm{Na}$ tests enabled direct comparisons to be made with untested material.

Samples were X-irradiated for 16 hours with unfiltered radiation from a chromium target operating at approximately $35 \mathrm{kV}$ with a beam current of about $25 \mathrm{~mA}$.

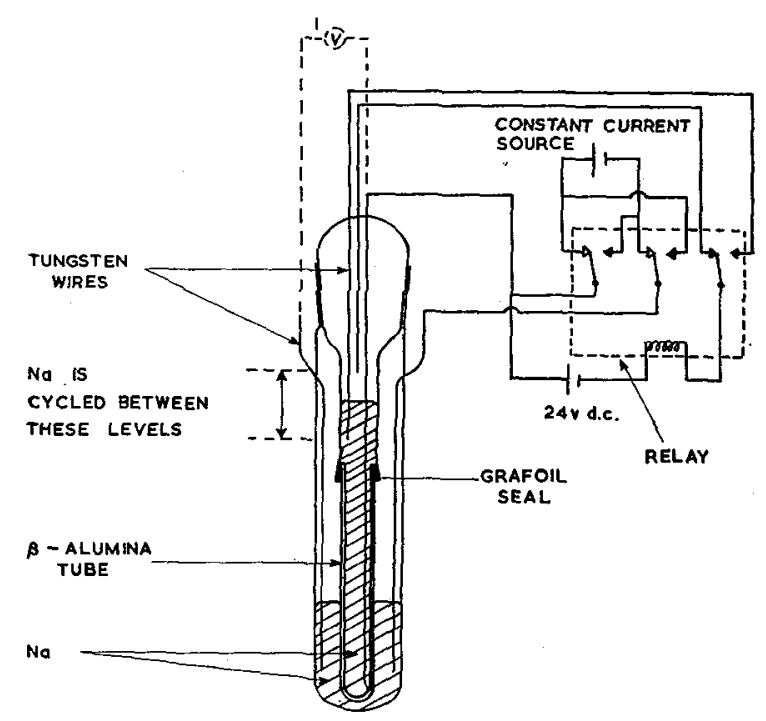

FIG. 2. - Apparatus used for sodium/beta alumina/sodium tests.

The equipment used for the thermoluminescence experiments consisted of a heated sample holder situated in an evacuable chamber. The sample temperature was raised linearly at approximately $14 \mathrm{~K} \cdot \mathrm{min}^{-1}$. Light from the sample passed through a glass window in the end of the chamber to a photomultiplier tube via a mechanical chopper unit contained in a light-tight box. The chopper also interrupted, simultaneously, the light from a bulb falling on to a photodiode, the output of which was used as the reference signal for a phase-sensitive detector. Glow curves were recorded directly on an $X-Y$ recorder. The frequency of the radiation emitted by the sample was determined by insertion of a plane grating monochromator between the chopper and photomultiplier.

3. Results. - 3.1 X-IRRAdiated SAmples. - Used (i. e. electrolysed) and unused samples of beta" alumina tubes were irradiated together and their glow curves compared; those for the Composition (A) material, as above, are shown in figure 3 . The unused sample shows two distinct peaks at $140{ }^{\circ} \mathrm{C}$ and $290{ }^{\circ} \mathrm{C}$, the higher temperature peak being of greater magnitude. Little significance can be placed on the total amount of light emitted from each sample as this depends on such variables as sample size and opacity and radiation dose. However, where direct comparisons have been made, as in figure 3, the samples were of the same size and were irradiated together.

The used sample shows a very similar low temperature peak, but there is no distinct high temperature peak, although there is still an appreciable emission. Spectral analysis of both peaks for the unused material indicated a single wavelength at $505( \pm 2) \mathrm{nm}$. The used material was also found to emit light of this 


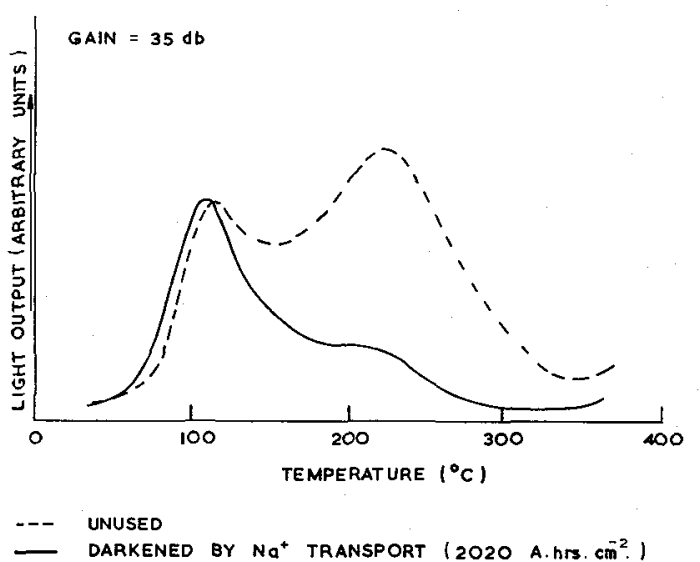

FrG. 3. - Glow curves for X-irradiated composition (A) beta" alumina.

wavelength, both at the low temperature peak and at higher temperatures.

The glow curves for used and unused samples of Composition (B) material were also compared and are shown in figure 4 . The two curves were found to be very similar, but the used sample had been on test for only 5.5 A.h. $\mathrm{cm}^{-2}$ before failure by penetration by dendrites. Only one peak was observed, although there was considerable light output at higher temperatures (i. e. the curves are very similar to those obtained for used Composition (A) material). The wavelength of the light from the unused material was found to be $506( \pm 2) \mathrm{nm}$.

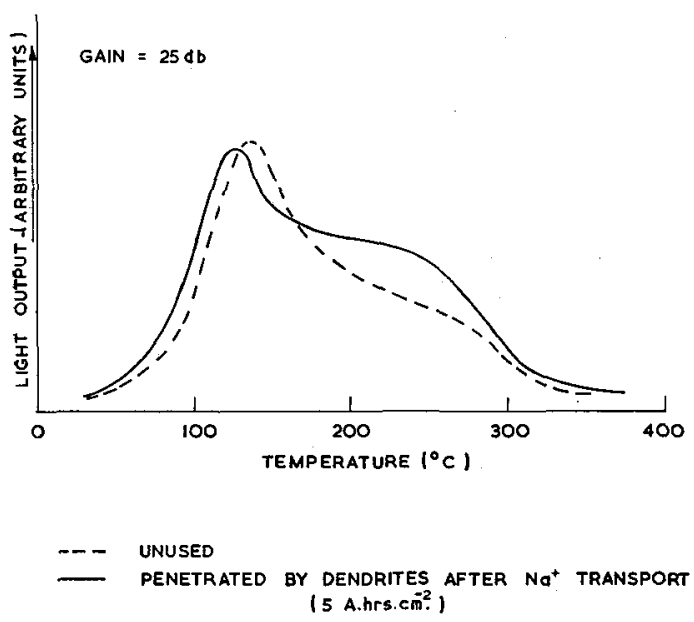

FrG. 4. - Glow curves for X-irradiated composition (B) beta" alumina.

3.2 NON-IRRADIATED SAMPLES. - Several samples which had become discoloured as a result of $\mathrm{Na}^{+}$transport in sodium/beta" alumina/sodium cells were tested. Within the limits of detection of the equipment, no light output could be detected between room temperature and about $250^{\circ} \mathrm{C}$; at higher temperatures, black body radiation from the sample chamber was detected which would have masked all but very strong luminescence from the sample. Figure 5 shows a typical result, the sample being a section of Composition (A) tube which exhibited general grey discolouration after $\mathrm{Na}^{+}$transport for a total of 580 A.h. $\mathrm{cm}^{-2}$ without any electronic conduction being detected. It was found, however, that the darkening had been removed during the thermoluminescence test.

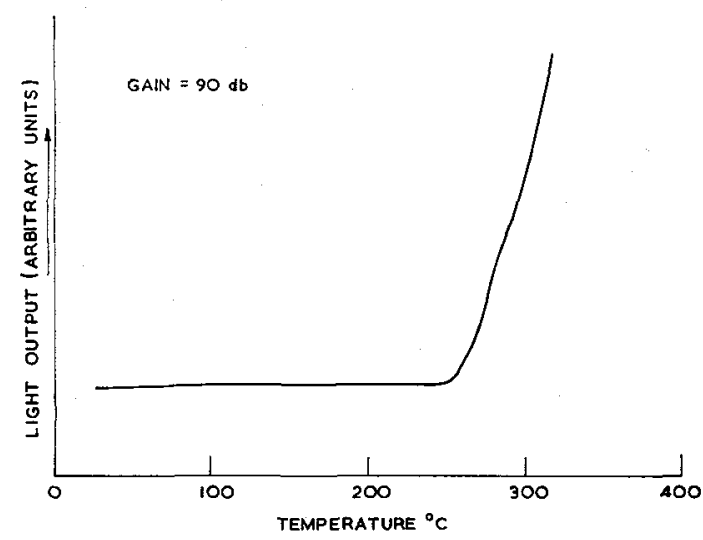

FIG. 5, - Glow curve for composition (A) beta" alumina darkened by $\mathrm{Na}^{+}$transport ( 580 A.h. $\mathrm{cm}^{-2}$ ).

3.3 MonofraX. - To obtain further information on the possible position of the defects in the lattice, an experiment was performed with an X-irradiated crystal of Monofrax. (This is $100 \%$ beta alumina, obtained from Harbison Carborundum Co. in the form of an undoped fusion cast brick.) The glow curve is shown in figure 6 . A single peak was observed at approximately

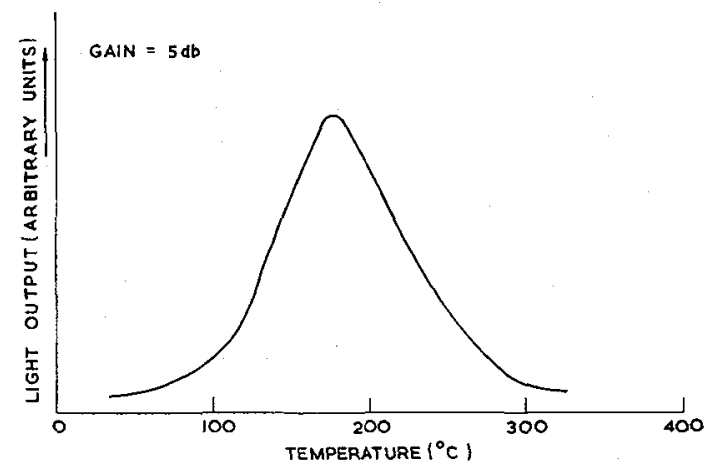

FIG. 6. - Glow curve for X-irradiated Monofrax beta alumina

$175^{\circ} \mathrm{C}$, which is considerably higher than the low temperature peaks found with both beta" materials and is also lower than the high temperature peak observed with Composition (A) material. The wavelength of the light was found to be $507( \pm 2) \mathrm{nm}$. 
3.4 Alpha alumina. - If the colour centres observed in beta alumina are sited in the spinel blocks, it might be expected that colour centres formed in alpha alumina would exhibit similar characteristics. The glow curve for an X-irradiated sample of re-crystallised alumina exhibited a single glow peak at about $160^{\circ} \mathrm{C}$. Two wavelength maxima were detected at about $692 \mathrm{~nm}$ and $424 \mathrm{~nm}$; these are not in good agreement with reported [14] absorption bands at 230, 400 and $650 \mathrm{~nm}$. However, no wavelength similar to that observed with the beta alumina samples was detected, and the nature of the glow curve was also quite different.

3.5 Samples heated In SOdium. - No light emission could be detected from a sample of Monofrax which had been blackened by heating in liquid sodium at $700{ }^{\circ} \mathrm{C}$. A curve similar to that shown in figure 5 was obtained.

A sample of Monofrax which had been darkened by heating in liquid sodium and then $\mathrm{X}$-irradiated gave a similar glow curve (Fig. 7) to the untreated crystal (Section 3.3) except that the light intensity was greatly reduced, presumably because of the blackening of the sample; the glow peak also occurred at a slightly higher temperature.

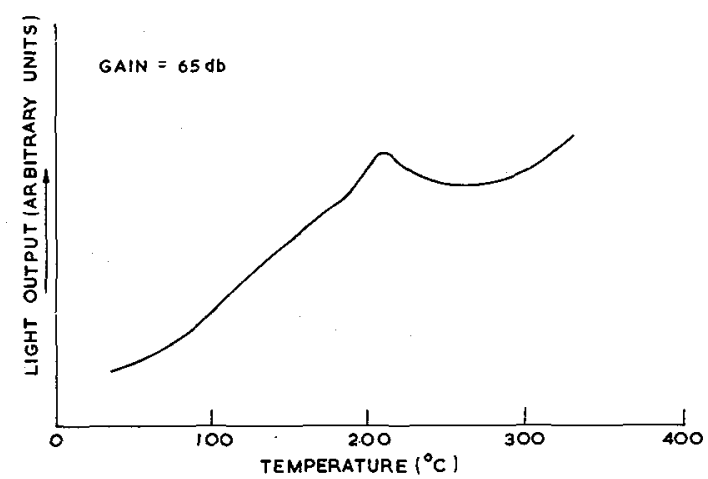

Fig. 7. - Glow curve for Monofrax beta alumina darkened by heating in sodium and then X-irradiated.

It was found that the darkening caused by heating in sodium was still present after the thermoluminescence experiments, in contrast to the samples discoloured by $\mathrm{Na}^{+}$transport. A separate test showed that this darkening was not removed until the specimen was heated to $900-1000^{\circ} \mathrm{C}$ in air.

4. Discussion. - The presence of two glow curve maxima in unused, X-irradiated material with light of the same wavelength would indicate that two F-centre energy levels exist within the material with the implication that holes are trapped at only one type of cation vacancy whilst there are two energetically different anion vacancies which can trap electrons to form F-centres.
The observation that for Composition (A) material the higher temperature peak almost disappears after $\mathrm{Na}^{+}$transport suggests that a large number of the associated traps are destroyed.

Light from all the samples (Monofrax, Compositions (A) and (B)) was of the same wavelength which implies that one type of cation vacancy is common to beta and beta" alumina. However, the number and depth of the electron traps appears to vary with composition. Thus, the number of traps associated with the lower temperature peak is similar in both (A) and (B), but more of the deeper traps are present in (A), some of which are removed by $\mathrm{Na}^{+}$transport. Since cation transport is restricted to the sodium containing planes between the spinel blocks $[15,16]$, then these observations are consistent with the defects being in, or adjacent to the sodium planes and that the number and depth of such traps are affected by the dopants. Further evidence that the defects are not sited within the spinel blocks is provided by the absence of any similarity between the luminescence of alpha alumina and beta alumina.

The overall band gap of beta" alumina, by analogy with other electronically insulating materials, is likely to be in the region of 9-11 eV. From the characteristic wavelength $(505 \mathrm{~nm})$ of the light emitted from the samples, the depth of the trapped hole centres is calculated to be $2.46 \mathrm{eV}$ below the conduction band. The empirical formula due to Urbach [17]

$$
E(\mathrm{eV})=\frac{T_{\max }(\mathrm{K})}{500}
$$

gives electron trap depths of 0.8 and $1.1 \mathrm{eV}$ for the low temperature $\left(\sim 120^{\circ} \mathrm{C}\right)$ and high temperature $\left(\sim 270^{\circ} \mathrm{C}\right)$ maxima respectively.

Considering, finally, the role that colour centres may play in the current darkening of beta" alumina we note that the discolouration associated with $\mathrm{Na}^{+}$transport is not the same as that obtained by heating the ceramic in the presence of sodium since the latter is not removed until the sample is heated to $\sim 900^{\circ} \mathrm{C}$ whereas the former is completely bleached during the thermoluminescence tests, i. e. $<380^{\circ} \mathrm{C}$. The absence of any detectable light emission from electrolysed beta" alumina indicates that $\mathrm{Na}^{+}$flux does not lead directly to the formation of colour centres stable at $350^{\circ} \mathrm{C}$ which is in accord with the experimentally determined bleaching temperature of $270^{\circ} \mathrm{C}$ for X-irradiation induced centres.

In this context the results of Thorp, Aypar and Ross [13] which showed by ESR the presence of F-centres in yttria stabilised zirconia which had been darkened by the passage of an anionic current at $800^{\circ} \mathrm{C}$ would suggest that the drap depth of the F-centre is at least $2.1 \mathrm{eV}$. This disparity in the stability of the F-centre in zirconia and beta" alumina makes it difficult to explain current darkening in beta" alumina by the same mechanism. 
5. Conclusions. - The main points which arise in this preliminary study are :

(i) Destruction of the centres in all the beta and beta" material examined has resulted in emission of light of a unique wavelength.

(ii) Two distinct electron traps have been noted for beta" alumina.

(iii) The predominance of one or both of the traps depends upon the dopant.

(iv) The evidence is consistent also with these traps existing in the sodium rich inter spinel block region of the lattice.

(v) No evidence of colour centres has been found in material darkened by sodium ion transport so that the nature of the darkening remains nuclear.

(vi) A substantial reduction in the population of the deeper trap $(1.1 \mathrm{eV})$ has been observed in darkened material and this may have significance in the breakdown mechanism during electrolysis ; further studies are in hand to elucidate this.

Acknowledgments. - The authors are indebted to Dr. D. L. Kirk of the Department of Electrical and Electronic Engineering, University of Nottingham, for allowing use of the thermoluminescence equipment and the facilities of the Department and for useful discussions. Thanks are also due to the British Railways Board for permission to publish this paper.

\section{References}

[1] Kummer, J. T. and WEBER, N., A Sodium/Sulphur Secondary Battery, Soc. of Automotive Engineers, Automotive Engineering Congress, Detroit, 1967.

[2] Sudworth, J. L. and Hames, M. D., Power Sources 2 (1970) Proc. of 7th International Symposium. D. H. Collins, Ed. (Oriel Press) 1971.

[3] Sudworth, J. L. ,Sulphur Inst. J. 8 (4) (1972) 12.

[4] Hames, M. D. and DunCan, J. H., The Function and Performance of Beta Alumina in Sodium/Sulphur Cells, Soc. of Automotive Engineers, Automotive Engineering Congress, Detroit 1975.

[5] Kummer, J. T., Prog. in Solid State Chem. 7 (1972) p. 141.

[6] Bragg, W. L., GotTfried, C. and West, J., Z. Krist. 77 (1931) 255.

[7] BeEvers, C. A. and Ross, M. A. S., Z. Krist. 97 (1937) 59.

[8] Yamaguchi, Y. and Suzuki, K., Bull. Chem. Soc. Japan 41 (1968) 93.
[9] Betrman, M. and Peters, C. R., J. Phys. Chem. 73 (1969) 1774.

[10] Armstrong, R. D., Dickinson, T. and Turner, J., Electrochim. Acta 19 (1974) 187.

[11] Richman, R. H. and Tennenhouse, G. J., J. Am. Ceram. Soc. 58 (1975) 63.

[12] Casselton, R. E. W., J. Appl. Electrochem. 4 (1974) 25.

[13] Thorp, J. S., AYPar, A. and Ross, J. S., J. Mater. Sci. 7 (1972) 729.

[14] Schulman, J. H. and Compton, W. D., Colour Centres in Solids (Pergamon Press) 1962.

[15] YAO, Y. F. Y. and Kummer, J. T., J. Inorg. Nucl. Chem. 29 (1967) 2453.

[16] Demott, D. S. and Hancock, P., Proc, Br. Ceram. Soc. 19 (1971) 193.

[17] URBACH, F., Wiener Ber. IIa 139 (1930) 363.

\section{DISCUSSION}

A. E. Hughes. - Is it possible that the defects which cause the darkening are colloidal platelets of metallic sodium in the mirror plane ?

Have any optical absorption (or diffuse reflectance) measurements been made which could help to characterize the defects?

D. S. DemotT. - It is possible that colloidal sodium could be deposited as a final stage of aggregation of F-centres. However, using various analytical tech- niques (E. P. M. A., S. E. M., E. S. C. A. and X-ray diffraction) no evidence has been found for the presence of metallic sodium in generally darkened material. Also, no electronic component of conduction has yet been detected in such material.

It is difficult to make optical measurements on polycrystalline material and experimental difficulties would arise in transporting $\mathrm{Na}^{+}$ions through single crystals for extended periods. 